\title{
FORMULASI TISU BASAH BAWANG MERAH (Allium Cepa var. Ascalonicum) DENGAN MINYAK ADAS (Oleum Foeniculum Vulgare) SEBAGAI KOMPRES DEMAM ALAMI
}

\author{
Zulfa Nurani Alfiyyah ${ }^{*}$, Dewi Ratnasari², Yusi Helmiawati ${ }^{3}$ \\ 1,2,3 Sekolah Tinggi Ilmu Kesehatan Holistik \\ *Korespondensi: Jl. Veteran No. 272 Ciseureuh Purwakarta, Email: zulfa.nurani.zn@gmail.com
}

\begin{abstract}
ABSTRAK
Latar Belakang: Demam adalah suatu keadaan dimana suhu tubuh diatas normal yaitu diatas $38^{\circ} \mathrm{C}$. Demam dapat diredakan dengan pengobatan sintetis dan pengobatan tradisional, salah satu tanaman obat yang dapat digunakan dalam pengobatan tradisional untuk mengendalikan demam adalah bawang merah (Allium Cepa var. Ascalonicum).

Tujuan Penelitian: Penelitian ini bertujuan untuk membuat tisu basah dari bawang merah (Allium Cepa var. Ascalonicum) dengan minyak adas (Oleum Foeniculum Vulgare) sebagai kompres demam instan atau siap pakai yang mengandung bahan alami.

Metode: Penelitian ini menggunakan metode penelitian tindakan (Action Research) menggunakan instrumen penelitian berupa lembar observasi dan angket uji kesukaan. Sediaan dibuat dengan komposisi antara bawang merah : minyak adas $(12: 1,12: 2,12: 3)$.

Hasil: Menunjukkan hasil sediaan tisu basah yang tahan lama dan stabil selama 3 minggu penyimpanan pada suhu ruangan $20^{\circ} \mathrm{C}-25^{\circ} \mathrm{C}$ secara uji organoleptik dengan proposi formula yang paling disukai responden adalah formula 3 dengan penambahan minyak adas sebanyak 3 ml yaitu aroma $84 \%$ dan warna $88 \%$.

Simpulan: Tisu basah stabil dalam penyimpanan selama 3 minggu pada suhu ruangan dan sediaan yang paling disukai oleh masyarakat yaitu formula ketiga dengan penambahan minyak adas sebanyak $3 \mathrm{ml}$.
\end{abstract}

Kata kunci: Bawang merah (Allium Cepa var. Ascalonicum), minyak adas (Oleum Foeniculum Vulgare), tisu basah, kompres demam.

\section{ABSTRACT}

Background: Fever is a condition where the body temperature is above normal which is above $38^{\circ} \mathrm{C}$. Fever can be relieved by synthetic medicine and traditional medicine, one of the medicinal plants that can be used in traditional medicine to control fever is red onion (Allium Cepa var. Ascalonicum).

Objective: The purpose of the study is to make wet tissue from red onoin (Allium Cepa var. Ascalonicum) with fennel oil (Oleum Foeniculum Vulgare) as an instant or ready-to-use fever compress containing natural ingredients.

Method: This research uses action research method to use research instruments in the form of observation sheets and a questionnaire test preferences. The preparation is made with a composition between red onion: fennel oil (12: 1, 12:2, 12:3).

Results: Shows the results of a wet tissue preparation that is durable and stable for 3 weeks of storage at room temperature $20^{\circ} \mathrm{C}-25^{\circ} \mathrm{C}$ by organoleptic test with the proposiation formula most preferred by respondents is formula 3 with the addition of $3 \mathrm{ml}$ of fennel oil which is $84 \%$ aroma and $88 \%$ color.

Conclusion: Wet wipes are stable in storage for 3 weeks at room temperature and the most preferred preparation by the public is the third formula with the addition of fennel oil as much as $3 \mathrm{ml}$.

Keywords: Red onion (Allium Cepa var. Ascalonicum), fennel oil (Oleum Foeniculum Vulgare), wet tissue, fever compress. 


\section{PENDAHULUAN}

Mengendalikan demam dilakukan dengan cara menurunkan suhu tubuh yang mengalami kenaikan diatas normal yaitu diatas $38^{\circ} \mathrm{C}$. Pada prinsipnya demam dapat menguntungkan dan dapat pula merugikan, pada tingkat tertentu demam merupakan bagian dari pertahan tubuh yang bermanfaat karena timbul dan menetap sebagai respon terhadap suatu penyakit, namun suhu tubuh yang terlalu tinggi juga akan berbahaya [1]. Oleh karena itu penanganan dini terhadap munculnya demam penting adanya demi menghindari hal-hal yang tidak inginkan.

Demam dapat diredakan dengan pengobatan sintetis dan pengobatan tradisional. Masyarakat sendiri khususnya masyarakat pedesaan untuk penanganan pertama pada orang yang mengalami demam biasanya lebih menggunakan pengobatan tradisional. Pengobatan dengan obat tradisional harganya murah dan terjangkau oleh setiap kalangan masyarakat dan mudah didapat karena jumlahnya melimpah. Salah satu tanaman obat yang digunakan untuk mengendalikan demam adalah bawang merah (Allium Cepa var. Ascalonicum). Bawang merah mengandung senyawa sulfur organik yaitu Allycysteine Sulfoxide (Allin) [2]. Secara empiris bawang merah (Allium Cepa var. Ascalonicum) sudah banyak digunakan oleh masyarakat dengan pengolahan yang sederhana yaitu dengan digerus kemudian dikompreskan atau ditempelkan langsung pada dahi.

Mengkompreskan langsung dengan cara menempelkan gerusan bawang merah pada dahi dapat menurunkan demam. Bawang merah yang digerus akan melepaskan enzim alliinase yang berfungsi sebagai katalisator untuk allin yang akan bereaksi dengan senyawa lain misalnya kulit yang berfungsi menghancurkan bekuan darah [3]. Gerusan bawang merah di permukaan kulit membuat pembuluh darah vena berubah ukuran yang diatur oleh hipotalamus arterior untuk mengontrol pengeluaran panas sehingga terjadi vasodilatasi (pelebaran) pembuluh darah dan hambatan produksi panas. Terjadinya vasodilatasi ini menyebabkan pembuangan panas melalui kulit meningkat, pori-pori membesar dan pengeluaran panas secara evaporasi (berkeringat) yang diharapkan akan terjadi penurunan suhu tubuh mencapai keadaan normal kembali [4]. Bawang merah juga akan melancarkan peredaran darah menjadi lancar dengan kandungan minyak atsirinya [5].

Berdasarkan pada penelitian yang pernah dilakukan pembuatan sediaan bawang merah (Allium Cepa var. Ascalonicum) meliputi sediaan patch ekstrak etanol bawang merah [6] dan gerusan bawang merah yang dikompreskan langsung [7]. Namun pada penelitian yang sudah dilakukan sediaan tersebut memiliki bau yang tidak enak dan sediaan tidak menggunakan pewangi alami. Sehingga penelitian saat ini yang akan dilakukan yaitu membuat sediaan kompres dengan bentuk berupa tisu basah yang mudah dan praktis saat digunakan untuk mengkompres demam dengan penambahan minyak adas (Olleum Foeniculum Vulgare) yang memiliki kandungan anetol [8] sebagai pewangi alami untuk menutupi bau tidak enak yang dihasilkan oleh bawang merah dengan menggunakan metode maserasi menggunakan etanol 70\%. Metode maserasi dianggap lebih menguntungkan karena untuk keamanan bahan-bahan atau zat yang tidak tahan terhadap pemanasan [9].

\section{METODE PENELITIAN}

Penelitian ini menggunakan metode penelitian tindakan (Action Research). Penelitian tindakan mengacu pada proses yang berganti secara terus menerus antara penyelidikan dan tindakan antara praktik dan berfikir inovatif [10]. Penelitian tindakan yang dilakukan oleh peneliti yaitu penggunaan bawang merah pada pembuatan tisu basah dengan cara menambahkan formula minyak adas.

\section{HASIL PENELITIAN}

\section{Hasil Pembuatan Tisu Basah Bawang Merah Dengan Minyak Adas Sebagai Kompres Demam Alami}

Proses pembuatan tisu basah ini dilakukan di Laboratorium Kimia STIKes Holistik Purwakarta pada tanggal 05 sampai 30 Juni 2020. Bahan yang digunakan dalam pembuatan tisu basah yaitu bawang merah 
dan minyak adas. Bawang merah yang digunakan diperoleh langsung dari daerah pasar Sawit, Purwakarta. Bagian yang digunakan adalah umbi bawang merahnya sedangkan untuk minyak adas diperoleh dari hasil produksi Happy Green dan hanya sebagai bahan tambahan (pewangi alami). Tahap selanjutnya bawang merah dibersihkan kemudian ditimbang dan digerus sedangkan minyak adas disiapkan sesuai konsentrasi yang diperlukan.

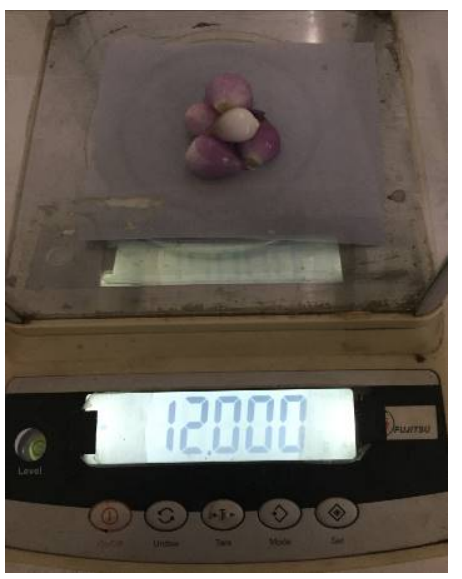

\section{Gambar 1. Proses Penimbangan (Dokumen Pribadi)}

Bawang merah tersebut diolah
dengan metode maserasi menggunakan
dari bawang merah.

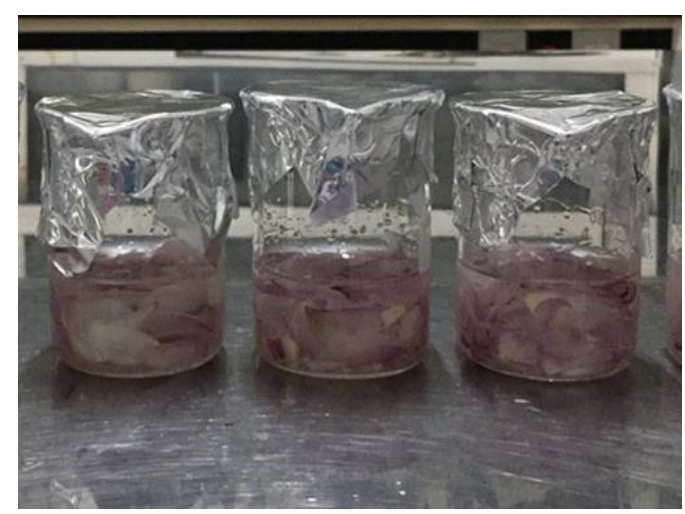

Gambar 2. Proses Maserasi (Dokumen Pribadi)

Maserasi bawang merah yang dilakukan mengacu pada Depkes RI, 1995 dengan cara merendam bawang merah yang telah ditumbuk didalam etanol $70 \%$ selama $3 \mathrm{x}$ 24 jam. Proses penumbukkan bawang merah menyebabkan terbukanya pori-pori bahan sehingga memudahkan larutnya komponen yang terdapat pada bahan kedalam pelarut akibat dari proses difusi [11]. 


\section{Hasil Maserasi}

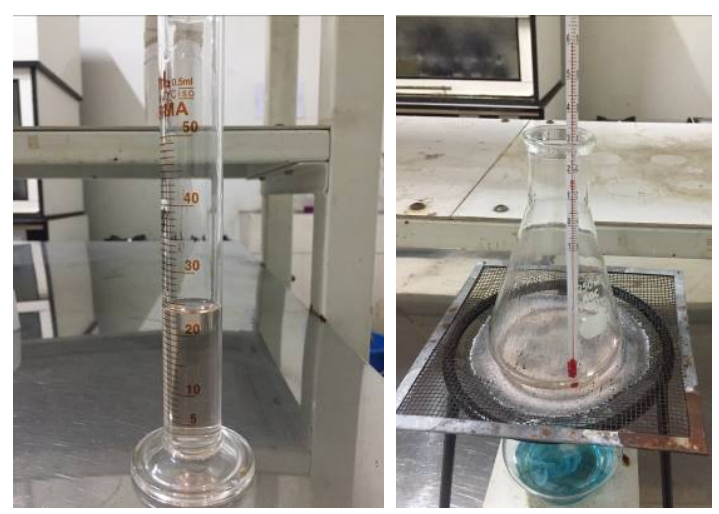

\section{Gambar 3. Hasil Maserasi dan Pemanasan (Dokumen Pribadi)}

Gambar 3 menunjukkan hasil dari maserasi bawang merah didapat sebanyak $24 \mathrm{ml}$ dan hasil maserasi bawang merah berupa ekstrak etanol bawang merah yang dipanaskan pada suhu $60^{\circ} \mathrm{C}$ sebagai proses sterilisasi.

Dalam penelitian ini pembuatan tisu basah untuk kompres demam mengacu secara empiris dengan menggunakan bawang merah dan menambahkan formula minyak adas [21], masing-masing formulasi dibuat dengan 3 (tiga) sampel untuk diuji pada suhu penyimpanan yang sama yaitu suhu ruangan $\left(20^{\circ} \mathrm{C}-25^{\circ} \mathrm{C}\right)$.

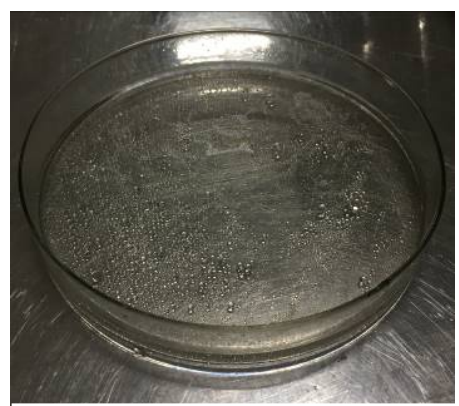

Formulasi 1

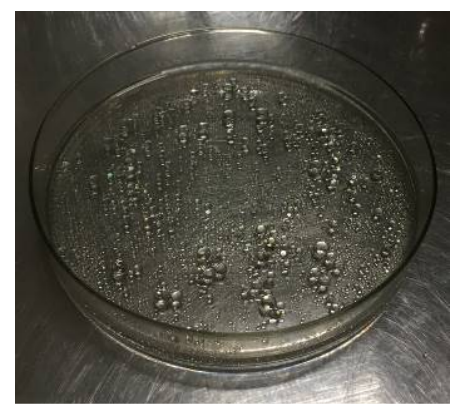

Formulasi 2

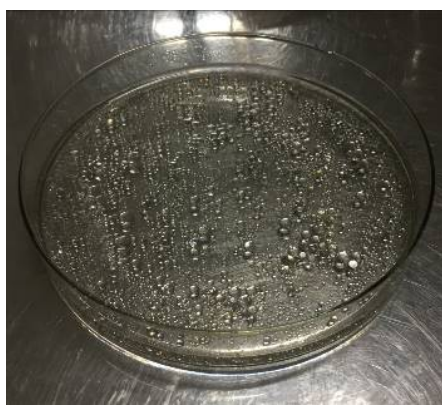

Formulasi 3

\section{Gambar 4. Proses Pencampuran (Dokumen Pribadi)}

Gambar formulasi 1 menunjukkan penambahan minyak adas sebanyak $1 \mathrm{ml}$, gambar formulasi 2 penambahan minyak

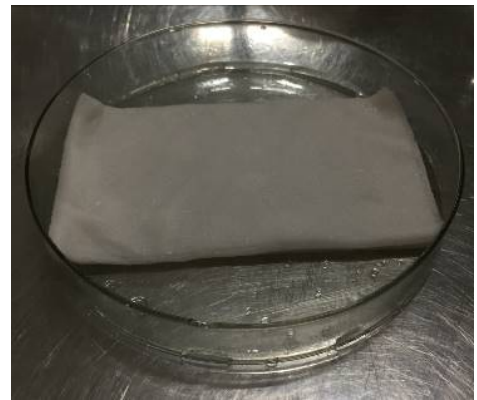

Formulasi 1

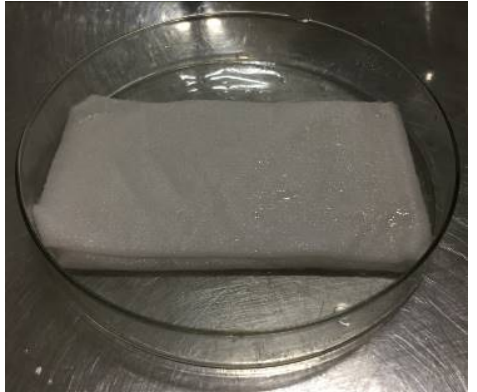

Formulasi 2 adas sebanyak $2 \mathrm{ml}$ dan gambar formulasi 3 penambahan minyak adas sebanyak $3 \mathrm{ml}$.

Gambar 5. Hasil Sediaan Jadi (Dokumen Pribadi) 
Gambar 5 menunjukkan hasil sediaan jadi yang mana campuran ekstrak etanol bawang merah dengan minyak adas dimasukkan tisu kering kedalamnya sehingga menjadi tisu basah. Hasil sediaan jadi pada formula 1 memiliki aroma dominan bawang merah, formula 2 memiliki aroma sama rata antara bawang merah dengan minyak adas dan formula 3 memiliki aroma dominan minyak adas sedangkan untuk bentuk dan warna sediaan dari ketiga formulasi tersebut memiliki bentuk yang lembab dan warna putih.

\section{Uji Organoleptik}

Tisu basah dari bawang merah (Allium Cepa var. Ascalonicum) dan minyak adas (Oleum Foeniculum Vulgare) telah selesai dibuat kemudian sediaan tersebut dilakukan pengujian organoleptik meliputi warna, bau dan bentuk sediaan selama 3 minggu penyimpanan pada suhu ruangan $20^{\circ} \mathrm{C}-25^{\circ} \mathrm{C}$ dengan pengamatan setiap 3 hari sekali. Kemudian hasil pengamatan tersebut dicatat dalam bentuk tabel 1 dan seterusnya.

Tabel 1. Hasil Uji Organoleptik 3 Hari Pertama

\begin{tabular}{|c|c|c|c|c|}
\hline \multirow[t]{2}{*}{ Sampel } & \multirow[t]{2}{*}{ Pengamatan } & \multicolumn{3}{|c|}{ Hari Ke- } \\
\hline & & 1 & 2 & 3 \\
\hline \multirow[t]{3}{*}{ F1 } & Warna & Putih & Putih & Putih \\
\hline & $\mathrm{Bau}$ & $\begin{array}{c}\text { Dominan bawang } \\
\text { merah }\end{array}$ & $\begin{array}{c}\text { Dominan bawang } \\
\text { merah }\end{array}$ & $\begin{array}{c}\text { Dominan bawang } \\
\text { merah }\end{array}$ \\
\hline & Bentuk & Lembab & Lembab & Lembab \\
\hline \multirow[t]{3}{*}{ F2 } & Warna & Putih & Putih & Putih \\
\hline & Bau & Dominan minyak adas & Dominan minyak adas & Dominan minyak adas \\
\hline & Bentuk & Lembab & Lembab & Lembab \\
\hline \multirow[t]{3}{*}{ F3 } & Warna & Putih & Putih & Putih \\
\hline & Bau & Sama rata & Sama rata & Sama rata \\
\hline & Bentuk & Lembab & Lembab & Lembab \\
\hline
\end{tabular}

Tabel 1 menunjukkan bahwa pada tiga hari pertama, sediaan yang disimpan dalam suhu ruangan tidak menunjukkan perubahan yang siginifikan dalam hal warna, bau dan bentuk sediaan.

Tabel 2. Hasil Uji Organoleptik 3 Hari Kedua

\begin{tabular}{ccccc}
\hline Sampel & Pengamatan & \multicolumn{3}{c}{ Hari Ke- } \\
& & $\mathbf{9}$ & $\mathbf{1 2}$ & $\mathbf{1 5}$ \\
\hline F1 & Warna & Putih & Puth & Puth \\
& Bau & Dominan bawang & Dominan bawang & Dominan bawang \\
& & merah & merah & merah \\
& Bentuk & Lembab & Lembab & Lembab \\
F2 & Warna & Putih & Puth & Putih \\
& Bau & Dominan minyak & Dominan minyak & Dominan minyak \\
& & adas & adas & adas \\
& Bentuk & Lembab & Lembab & Lembab \\
F3 & Warna & Putih & Puth & Puth \\
& Bau & Sama rata & Sama rata & Sama rata \\
& Bentuk & Lembab & Lembab & Lembab \\
\hline
\end{tabular}

Tabel 2 menunjukkan bahwa pada tiga hari kedua, sediaan yang disimpan dalam suhu ruangan tidak menunjukkan perubahan yang signifikan dalam hal warna, bau dan bentuk sediaan. 
Tabel 3. Hasil Uji Organoleptik 3 hari ketiga

\begin{tabular}{cccc}
\hline Sampel & Pengamatan & \multicolumn{2}{c}{ Hari Ke- } \\
\hline F1 & Warna & Putih & P1 \\
& Bau & Dominan bawang & Dominan bawang \\
& merah & merah \\
& Bentuk & Lembab & Lembab \\
F2 & Warna & Putih & Putih \\
& Bau & Sama rata & Sama rata \\
& Bentuk & Lembab & Lembab \\
F3 & Warna & Putih & Putih \\
& Bau & Dominan minyak & Dominan minyak \\
& & adas & adas \\
& Bentuk & Lembab & Lembab \\
\hline
\end{tabular}

Tabel 3 menunjukkan bahwa pada tiga hari ketiga, sediaan yang disimpan dalam suhu ruangan tidak menunjukkan perubahan yang signifikan dalam hal warna, bau dan bentuk sediaan.

Berdasarkan pengujian organoleptik selama tiga minggu dengan pengamatan 3 hari sekali dapat disimpulkan bahwa dari tabel 1-3 menunjukkan hasil pengujian organoleptik yang dilakukan peneliti dalam suhu penyimpanan yang sama yaitu suhu ruangan $20^{\circ} \mathrm{C}-25^{\circ} \mathrm{C}$ tidak menimbulkan perubahan yang signifikan dalam hal warna, bau maupun bentuk sediaan. Tidak terjadinya perubahan setelah uji organoleptik diperkirakan dari adanya proses pemanasan yang dilakukan peneliti sebagai proses sterilisasi dalam pembuatan sediaan.

\section{Hasil Presentase Uji Kesukaan}

Tabel 4. Hasil Presentase Uji Kesukaan

\begin{tabular}{|c|c|c|c|c|}
\hline \multirow{2}{*}{$\begin{array}{c}\text { Jenis yang } \\
\text { diuji }\end{array}$} & \multirow[t]{2}{*}{ Kode Sampel } & \multicolumn{3}{|c|}{ Skor } \\
\hline & & F1 (\%) & F2 (\%) & F3 (\%) \\
\hline \multirow[t]{4}{*}{ Aroma } & Sangat Tidak Suka & 12 & 0 & 0 \\
\hline & Tidak Suka & 48 & 16 & 4 \\
\hline & Normal & 36 & 52 & 12 \\
\hline & Suka & 4 & 32 & 84 \\
\hline \multirow[t]{2}{*}{ Warna } & Normal & 20 & 16 & 12 \\
\hline & Suka & 80 & 84 & 88 \\
\hline \multicolumn{5}{|l|}{1007} \\
\hline \multicolumn{5}{|l|}{$90-$} \\
\hline \multicolumn{5}{|l|}{$80-$} \\
\hline \multicolumn{5}{|l|}{70} \\
\hline \multicolumn{5}{|l|}{60} \\
\hline \multicolumn{5}{|r|}{ F1 } \\
\hline \multicolumn{5}{|l|}{$40-$} \\
\hline \multicolumn{5}{|l|}{30} \\
\hline \multicolumn{5}{|l|}{20} \\
\hline 20 & & & & \\
\hline \multicolumn{5}{|l|}{10} \\
\hline & Aroma & & & \\
\hline
\end{tabular}

Gambar 6. Diagram Hasil Presentase Uji Kesukaan 
Adapun hasil dari penelitian ini didapatkan sediaan berupa tisu basah kompres demam alami sebagai berikut :

Tabel 5. Hasil Tisu Basah dari Bawang Merah dengan Minyak Adas

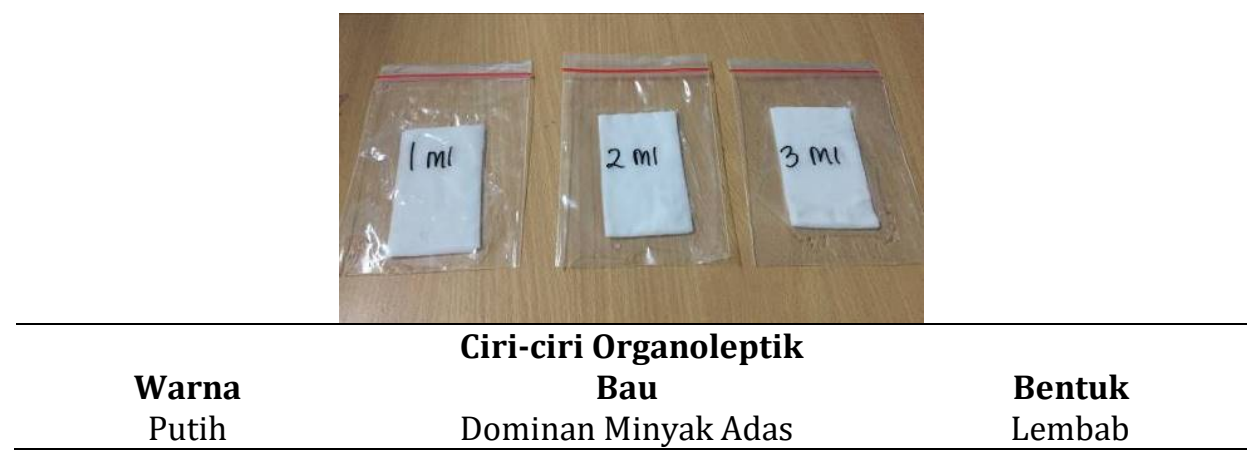

\section{PEMBAHASAN}

Berdasarkan pengamatan pra penelitian yang peneliti lakukan yaitu melakukan wawancara kepada masyarakat Desa Darangdan Rt. 26/07 Kec. Darangdan Kab. Purwakarta dengan tujuan untuk memperoleh data empiris penggunaan bawang merah yang digunakan sebagai penggunaan demam secara alami. Bawang merah ternyata biasa digunakan untuk penanganan demam di masyarakat dengan pengolahan yang sederhana yaitu dengan menggerus bawang merah dan mengkompreskannya langsung.

Dengan demikian bawang merah peneliti gunakan sebagai bahan utama pada pembuatan sediaan tisu basah kompres demam. Tisu basah kompres demam dibuat dari ekstrak etanol bawang merah, ekstrak etanol bawang merah didapatkan dari proses maserasi. Pada proses maserasi, bahan kandungan sel berpindah dengan terlarut dalam molekuler pelarut dengan berdifusi melalui rongga antar sel, gaya yang bekerja adalah perbedaan konsentrasi antara larutan di dalam sel dengan pelarut yang mula-mula tanpa bahan aktif [12]. Selanjutnya ekstrak etanol bawang merah dipanaskan dalam suhu $60^{\circ} \mathrm{C}$ sebagai proses sterilisasi.

Dapat dilihat dari hasil uji organoleptik sediaan yang telah dilakukan dan diamati selama 3 minggu tidak mengalami perubahan yang signifikan. Pada pengamatan hari ke-1 sampai hari ke-21 ketiga sampel tersebut tetap memiliki warna putih, bau seseuai dengan formulasi yang mana formula 1 dominan bawang merah, formula 2 sama rata antara bawang merah dengan minyak adas dan formula 3 memiliki abau dominan minyak adas Sedangkan untuk tampilan warna dan bentuk dari ketiga formula tidak ada perbedaan yang signifikan dengan warna putih dan bentuk tisu basah yang lembab. Tidak terjadinya perubahan setelah uji organoleptik sesuai dengan tujuan dari pemanasan dalam suhu $60^{\circ} \mathrm{C}$ selain sebagai sterilisasi tujuan lainnya untuk mengawetkan. Pengawetan dengan proses pemanasan ini memiliki cara kerja dengan membunuh organisme yang merugikan seperti bakteri, virus, protozoa, kapang dan khamir sehingga dapat memperpanjang daya simpan [13]. Hal ini menunjukkan bahwa sediaan tisu basah dari bawang merah (Allium Cepa var. ascalonicum) dan minyak adas (Oleum Foeniculum. Vulgare) stabil dalam penyimpanan selama 3 minggu.

Hasil pengamatan yang tertera pada tabel 4 dan gambar 6 menunjukkan hasil uji kesukaan 25 responden terhadap sediaan tisu basah dari bawang merah (Allium Cepa var. ascalonicum) dan minyak adas (Oleum Foeniculum. Vulgare) menghasilkan data yang menunjukkan persentase kesukaan pada formula 1 rendah yaitu untuk aroma $4 \%$, warna $80 \%$, formula 2 sedang yaitu untuk aroma $32 \%$, warna $84 \%$ dan formula 3 tinggi yaitu untuk aroma 84\%, warna 88\%. Dosis ekstrak etanol bawang merah dengan minimal 9 gram mampu menurunkan suhu tubuh yang mengalami demam [14]. Oleh karena itu peneliti yang 
menggunakan data empiris 12 gram umbi bawang merah digunakan untuk mendapatkan ekstrak etanol bawang merah sebanyak 9 gram untuk menentukan dosis yang sesuai. Penentuan dosis yang efektif juga dilakukan dengan membuat formulasi minyak adas $1 \mathrm{ml}$ sebagai dosis awal untuk pewangi alami dengan variasi pada formula 2 sebanyak $2 \mathrm{ml}$ dan pada formula 3 sebanyak $3 \mathrm{ml}$. Dari hasil uji kesukaan diperoleh data bahwa dari segi aroma, warna dan bentuk yang banyak disukai oleh masyarakat yaitu sampel formula 3 dengan komposisi bawang merah 12 gram dan minyak adas $3 \mathrm{ml}$. Hal ini dikarenakan minyak adas dengan kandungan anetol [15] sebanyak $3 \mathrm{ml}$ mampu menutupi aroma tidak enak yang dihasilkan oleh bawang merah.

\section{SIMPULAN}

Berdasarkan hasil pengamatan dan analisis data yang dilakukan maka dapat disimpulkan bahwa sediaan tisu basah dibuat dengan melakukan maserasi bawang merah dengan etanol $70 \%$ untuk mendapatkan ekstrak etanol bawang merah sebagai bahan utama pembuatan sediaan dan minyak adas sebagai pewangi alami. Hasil uji organoleptik yang dilakukan pada ketiga formulasi tersebut tidak menunjukkan perubahan yang signifikan yaitu pada formula 1 memiliki aroma dominan bawang merah, formula 2 memiliki aroma sama rata antara bawang merah dengan minyak adas dan formula 3 memiliki aroma dominan minyak adas sedangkan untuk bentuk dan warna sediaan ketiga formulasi memiliki bentuk yang lembab dan berwarna putih. Perbedaan pada aroma tersebut dipengaruhi oleh penambahan minyak adas pada setiap formulasi dengan jumlah yang berbedabeda yaitu minyak adas formula 1 sebanyak $1 \mathrm{ml}$, formula 2 sebanyak $2 \mathrm{ml}$ dan formula 3 sebanyak $3 \mathrm{ml}$. Hasil uji kesukaan menunjukkan bahwa formula 3 dengan komposisi 12 gram bawang merah dan $3 \mathrm{ml}$ minyak adas merupakan formulasi yang banyak disukai dengan presentase aroma $84 \%$ dan warna $88 \%$.

\section{DAFTAR PUSTAKA}

1. Cahyaningrum, E. D., Anies, A., \& Julianti, H. P. (2014). Perbedaan kompres hangat dan kompres bawang merah terhadap penurunan suhu tubuh anak dengan demam. Bhamada: Jurnal Ilmu dan Teknologi Kesehatan (E-Journal), 5(1), 10-10.

2. Cahyaningrum, E. D. (2017). Pengaruh Kompres Bawang Merah Terhadap Suhu Tubuh Anak Demam.Bidan Prada: Jurnal Publikasi Kebidanan Akbid YLPP Purwokerto.

3. Departemen Kesehatan Republik Indonesia. (2008). Farmakope Herbal Indonesia. Edisi 1. Departemen Kesehatan Republik Indonesia: Jakarta.

4. Irwan. 2010. Ekstraksi Menggunakan Proses Infudasi, Maserasi, dan Perkolasi. (Terhubung Berkala). http://www.irwanfarmasi.blogspot.co $\mathrm{m} / 2010$. (11 November 2019).

5. J.H. Tiner, Louis Pasteur - Founder of Modern Medicine, Mott Media, Milford (Michigan), 1990, hlm 18.

6. Kaneshiro, N.K., and Zieve, D. (2010). Fever. University of Washington. Available from: http://www.nlm.nih.gov/medlineplus/ ency/article/000980 .htm. [Updated 24 November 2019]

7. Kariyaningtias, V., Hamid, I. S., \& Widodo, T. (2019). Uji antipiretik patch ekstrak etanol bawang merah (allium ascalonicum l.) dengan matriks kitosan dan enhancer span-80 terhadap temperatur dan jumlah makrofag pada tikus putih. Jurnal Farmasi Sains dan Terapan, 5(2), 8793.

8. Maharani, N. M. (2019). Pengaruh Kompres Bawang Merah terhadap Penurunan Suhu Tubuh pada Pasien Demam Thypoid di RS PKU Muhammadiyah Gombong (Doctoral dissertation, STIKes Muhammadiyah Gombong).

9. Noor, Muhammad. 2010. Pemanfaatan Tanaman Tradisional dan Herbal. Bandung: CV. Advindo Buana Karya. 
10. Putri, Diannike, Dkk. 2017. Perbedaan Suhu Tubuh Anak Demam Sebelum dan Sesudah Kompres Bawang Merah. Dalam Medisains: Jurnal Ilmiah Ilmuilmu Kesehatan Volume 15 No 2 (hlm. 68). Purwokerto.

11. Rachmad, Sri Suryani, dan Paulus Lobo Gareso. (2012). Penentuan Efektifitas Bawang Merah dan Ekstrak Bawang Merah (Allium Cepa var. ascalonicum) dalam Menurunkan Suhu Badan. Program Studi Fisika, Jurusan Fisika, Fakultas MIPA, UNHAS Makassar.

12. Sukasih, Erni. Prabawati, Sulusi. Hiadayat, Tatang. 2009. Optimasi Kecukupan Panas Pada Pasteurisasi Santan Dan Pengaruhnya Terhadap Mutu Santan Yang Dihasilkan. Jurnal Pascapanen. Vol 6. No 1.

13. Soemiati, A. (2013). Perbandingan Metode Ekstraksi Maserasi dan Sokletasi Terhadap Kadar Piperin Buah Cabe Jawa (Piperis retrofracti fructus).

14. Sonhaji, Aang. 2014. Bertambah Tanaman Rempah. Bandung: CV. Sagita Publishing.

15. Taylor, Matthew (2017). "Wet Wipes Make Up 93\% of Matter Causing UK
Sewer Blockages". The Guardian. Diakses tanggal 10 Desember 2019.

16. Teddy, B. S. (2011). Pemodelan Proses Ekstraksi Ultrasonik Oleresin dan Cinnamaldehyde dari Kayu Manis (Doctoral dissertation, Universitas Diponegoro).

17. Trubus, Tim. 2013. Herbal Indonesia Berkhasiat Bukti Ilmiah dan Cara Racik Vol. 08. Jakarta: Trubus.

18. Uma Sekaran. 2006. Metodologi Penelitian Untuk Bisnis. Jakarta: Salemba Empat.

19. Utami, Prapti. 2008. Buku Pintar Tanaman Obat. Jakarta Selatan: PT Agromedia Pustaka.

20. Widjaja, M. C. 2001. Mencegah dan Mengatasi Demam pada Balita. Jakarta: Kawan Pustaka.

21. Willyanto, J. R., Hamid, I. S., \& Widodo, T. (2018). Uji antipiretik patch ekstrak etanol bawang merah (Allium ascalonicum L.) dengan matriks chitosan dan Enhancer Tween80. Jurnal Farmasi Sains dan Terapan, 5(1), 53-58.

22. Zaini Hasan, M. 1990. Karakteristik Penelitian Kualitatif. Malang: Yayasan Asih Asah Asuh. 